\title{
Medikamentoverforbruk ved kronisk hodepine
}

\section{En avhengighetsskala kan avdekke medikamentoverforbruk blant per- soner med kronisk hodepine.}

Kronisk hodepine er definert som smerter $>15$ dager per måned i minst tre måneder og forekommer hos rundt $3-4 \%$ av nordmenn $(1,2)$. Halvparten av disse har også et medikamentoverforbruk. Ved Akershus universitetssykehus har man nå testet ut en medikamentavhengighetsskala for å undersøke om den kan avdekke medikamentoverforbruk i denne gruppen (3). Severity of Dependence Scale (SDS) består av fem korte spørsmål: Tror du din bruk av medikamenter er ute av kontroll? Blir du engstelig eller bekymret ved tanken på å droppe en dose? Er du bekymret for ditt medikamentforbruk? Ønsker du at du kunne slutte å bruke medikamentene? Hvor vanskelig synes du det er å la være å ta/slutte med medikamentene?

30000 personer fra Akershus mottok spørreskjema om kronisk hodepine. 405 personer med kronisk hodepine ble inkludert i studien. SDS-skår var signifikant høyere blant dem med enn dem uten medikamentoverforbruk (5,6 versus 2,7).
Overforbruket var hyppigst for håndkjøpsanalgetika og kombinasjonsanalgetika, mens overforbruk av triptaner, ergotamin og opioider var sjeldent.

SDS-skåren kan trolig også brukes til å avdekke avhengighetsliknende atferd. Det vil si at personer med hyppig hodepine kan testes med denne skalaen for å angi sannsynligheten for fremtidig medikamentoverforbruk, men dette krever ytterligere studier for å bli bekreftet.

\section{Michael Bjørn Russell}

m.b.russell@medisin.uio.no

Forskningssenteret

Akershus universitetssykehus

\section{Litteratur}

Grande RB, Aaseth K Gulbrandsen P et al. Prevalence of primary chronic headache in a populationbased sample of 30- to 44-year-old persons. The Akershus study of chronic headache. Neuroepidemiology 2008; 30: 76-83

2 Aaseth K, Grande RB, Kværner KJ et al. Prevalence of secondary chronic headaches in a population-based sample of 30-44-year-old persons. The Akershus study of chronic headache. Cephalalgia 2008: 28: 705-13

3. Grande RB, Aaseth K, Šaltytë-Benth J et al. The severity of dependence scale detects those at risk of medication overuse. The Akershus study of chronic headache. J Neurol Neurosurg Psychiatry 2009: doi: 10.1136/jnnp.2008.168864.

\section{Mye bortkastet forskning?}

\section{Bare halvparten av forskningspro- sjekter innen klinisk legemiddelut- prøvning i Norge blir publisert. Man kan trolig vinne mye på bedre plan- legging}

Når et forskningsprosjekt startes, er det en forutsetning at studien blir fullført og at resultatet publiseres, helst $\mathrm{i}$ et internasjonalt tidsskrift med fagfellevurdering. Det er ukjent hvor ofte medisinske prosjekter blir avbrutt eller hvor stor andel fullførte prosjekter som blir publisert i et vitenskapelig tidsskrift. Vi har analysert et materiale på 245 forskningsprosjekter ( $98 \%$ av alle tilgjengelige) innen klinisk legemiddelutprøvning vurdert av de regionale forskningsetiske komiteer for medisin i år 2000 med henblikk på disse spørsmålene (1).

I 178 (73\%) prosjekter ble forskningsfasen gjennomført som planlagt. Prosjekter initiert av den farmasøytiske industrien ble hyppigere fullført enn prosjekter som var initiert eller finansiert på annen måte (76\% versus $63 \%) .67$ (27\%) av prosjektene ble avbrutt pga. for få pasienter, lokale praktiske problemer og uheldige virkninger av medikamentet. For 27 prosjekter kunne ikke prosjektleder angi noen begrunnelse. Resultater fra 131 (54\%) prosjekter ble publisert i et vitenskapelig tidsskrift, 34 $(14 \%)$ ble rapportert som kongressreferat eller rapport til sponsor, og 80 (33\%) ble ikke publisert.

Siden det ikke finnes noen tilsvarende studier, er det vanskelig å si om en publikasjonsprosent på $54 \mathrm{og}$ at $46 \%$ av prosjektene fikk ingen eller begrenset publisitet er godt eller dårlig. Må det være slik at for hvert vellykkede forskningsprosjekt som ender som en vitenskapelig publikasjon, vil det være ett mislykket prosjekt som skrinlegges? I så fall er det store ressurser som er bortkastet. Bedre planlegging av forskningsprosjekter vil trolig kunne øke andelen som resulterer i en publikasjon.

\section{Sigurd Nitter-Hauge}

s.l.nitter-hauge@medisin.uio.no Oslo

\section{Litteratur \\ 1. Hole OP, Nitter-Hauge S, Cederkvist HR et al. An analysis of the clinical development of drugs in Norway for the year 2000: the completion of research and publication of results. Eur J Clin Pharmacol 2009; 65: 315-8.}

\section{Stroma påvirker respons på cellegift}

Et europeisk samarbeidsprosjekt har analysert 63 østrogenreseptornegative brystkreftsvulster fra pasienter inkludert i studien EORTC10994. Pasientene fikk preoperativ kjemoterapi med 5-fluorouracil, epirubicin og cyklofosfamid (FEC) (Nat Med 2009; 15: 68-74).

Forskergruppen fant at økt uttrykk av såkalte stromale gener fra vevet omkring svulsten indikerte redusert respons på kjemoterapien. De undersøkte deretter samme genuttrykksmønster i to andre pasientgrupper og fant at mønsteret kunne predikere respons til cellegiftkombinasjonen, men at det ikke hadde prognostisk verdi. Forfatterne mener at terapi rettet mot vevet omkring svulsten vil bli viktig.

\section{HDL-kolesterol og koronar hjertesykdom}

Studier har identifisert HDL-kolesterol som en sterk, uavhengig, invers prediktor for koronar hjertesykdom. En internasjonal forskergruppe har nå undersøkt hvordan behandling som fører til økning i HDL-kolesterol påvirker risiko for koronar hjertesykdom og totaldødelighet (BMJ 2009; 338: b92).

Metaanalysen omfattet 109 randomiserte studier med 300000 deltakere utsatt for kardiovaskulære hendelser. Alle analyser som justerte for endringer i LDL-kolesterol, viste at det ikke var noen sammenheng mellom behandlingsinduserte endringer i HDLkolesterol og koronar hjertesykdom og totaldødelighet. En reduksjon i LDL-kolesterol førte derimot til relativ risikoreduksjon, og dette bør være primærmålet for lipidmodifiserende intervensjon.

\section{Alkoholmisbruk fører til depresjon - ikke omvendt}

Alkoholmisbruk og depresjon forekommer ofte samtidig. Dette skyldes dels at de samme risikofaktorene disponerer både for alkoholmisbruk og depresjon, og dels at det ene fører til det andre. Men er det misbruk som gir depresjon, eller bruker den deprimerte alkohol for å døyve plagene?

Resultatene av en oppfølgingsundersøkelse fra New Zealand peker mot det første alternativet (Arch Gen Psychiatry 2009; 66: 260-6). Nesten 1300 personer ble intervjuet tre ganger $\mathrm{i}$ ung voksen alder. Forekomsten av både alkoholmisbruk og depresjon var relativt høy (omkring $20 \%$ for begge). Forskerne brukte avansert strukturell likningsmodellering. En modell der alkoholmisbruk førte til depresjon passet bedre med dataene enn alternative modeller for kausalitet. 